\title{
USE OF THE SSIB4/TRIFFID MODEL COUPLED WITH TOPMODEL TO INVESTIGATE THE EFFECTS OF VEGETATION AND CLIMATE ON EVAPOTRANSPIRATION AND RUNOFF IN A SUBALPINE BASIN OF SOUTHWESTERN CHINA
}

\author{
Huiping DENG ${ }^{1}$, Li DAN ${ }^{2}$, Huanguang DENG ${ }^{1}$, Yan XIAO ${ }^{1}$, Qian WANG ${ }^{1}$ \\ ${ }^{1}$ School of Environment and Planning, Liaocheng University, 252059 Liaocheng, China \\ ${ }^{2}$ CAS Key Laboratory of Regional Climate-Environment Research for Temperate East Asia, \\ Institute of Atmospheric Physics, Chinese Academy of Sciences, 100029 Beijing, China
}

Received 14 July 2020; accepted 30 March 2021

\footnotetext{
Highlights

> The SSiB4T/TRIFFID coupled model was developed by integrating the biophysical/dynamic vegetation model SSiB4/TRIFFID with TOPMODEL.

Long-term simulations of vegetation dynamics and water balances were performed under different climate scenarios for the Suomo River Basin in the sub-alpine mountain region.

$\checkmark$ The role of forests in increasing runoff changes to a reduction in runoff as the temperature increases or the altitude decreases.

The climate exerts a dominant control on the forest-runoff relationship.
}

\begin{abstract}
It is important to understand the response of vegetation dynamics and surface water budget to the changing climate. To investigate the effects of vegetation and climate change on evapotranspiration and runoff on a basin scale, the SSiB4T/TRIFFID (SSiB4/TRIFFID coupled with TOPMODEL) is used to perform long-term dynamic simulations of vegetation succession and the water balance under different climate scenarios for a subalpine basin. The results of all experiments show that fraction of vegetation changes from a dominance of C3 grasses to tundra shrubs and then gradually approaches equilibrium with a dominance of forests. Change to evapotranspiration is very sensitive to temperature changes but is not sensitive to precipitation changes when the temperature remains unchanged. Runoff is very sensitive to changes in both temperature and precipitation. In the increase of temperature, evapotranspiration of forests increases the most among the three vegetation types. From the control run to the $[\mathrm{T}+5,(1+40 \%) \mathrm{P}]$ run $\left(\mathrm{A}\right.$ temperature increase of $5{ }^{\circ} \mathrm{C}$, an increase in precipitation of $40 \%)$, the role of forests in increasing runoff changes to a reduction in runoff.
\end{abstract}

Keywords: coupled model SSiB4T/TRIFFID, dynamic simulations, vegetation succession, water balances, impacts of vegetation and climate change, effects of forest vegetation on runoff.

\section{Introduction}

The Earth's climate is the dominant control on the spatial distribution of the major vegetation types on a global scale (Woodward et al., 2004) and the composition and distribution of plant communities are of fundamental importance for evapotranspiration and the generation of runoff (Dunn \& Mackay, 1995). Plants affect runoff via features such as albedo and interception, stomatal behavior and transpiration, rooting strategy, leaf area and phenology (Dunn \& Mackay, 1995). There are three different perspectives on the relationship between forests and runoff (Li et al., 2001): (1) forests increase runoff; (2) there is no clear relationship between forests and runoff; and (3) forests reduce the annual runoff from a region. A general conclusion drawn from small watershed $\left(<1000 \mathrm{~km}^{2}\right)$ studies is that a reduction in forest cover increases runoff by decreasing evapotranspiration, whereas reforestation usually decreases runoff (Bosch \& Hewlett, 1982; Li et al., 2001; Zhang et al., 2017). However, there have been some inconsistent responses, suggesting the response intensity

*Corresponding author. E-mail: danli@tea.ac.cn 
of annual runoff to forest cover change can be variable among watersheds and a general conclusion on the relationship between forest change and annual runoff in large watersheds $\left(>1000 \mathrm{~km}^{2}\right)$ has not yet been drawn (Zhang et al., 2017).

The southwestern forest area of China is the second largest area of natural forest in China and is located on the southeastern Qinghai-Tibetan Plateau. This forest area includes the Hengduan Mountains at the junction of Sichuan, Yunnan and Tibet. The large difference in altitude in this region results in a distinct vertical zonation of the climate. Forests are mainly found on the middle and lower slopes below $4000 \mathrm{~m}$. Alpine shrubs are found above $4000 \mathrm{~m}$, subalpine coniferous forests from 3000 to $3800 \mathrm{~m}$, and coniferous and broadleaf mixed forests between 2500 and $3000 \mathrm{~m} \mathrm{(Ma,1987).} \mathrm{The} \mathrm{southwestern} \mathrm{forest} \mathrm{area} \mathrm{is}$ an important area for the production of timber and water and is also sensitive to changes in climate. The effect of forests on runoff has been carried out in this region since the beginning of the 1960s to study the impact of deforestation (or afforestation) on the runoff from rivers (Ma, 1987; Zhang et al., 2007, 2012).

There has been a long-term debate about whether forests increase or decrease runoff or whether they have no significant effect on runoff (Li et al., 2001). Traditional forest watershed comparison studies focus on the relationship between changes in vegetation and runoff from the watershed. It is impossible to analyze the processes and mechanisms of the hydrological impact of forest vegetation. It is difficult to fundamentally understand the role of forest vegetation in hydrology and to explain the relationship between forests and runoff. Climate change will lead to changes in surface vegetation and the water-carbon balance within the basin. However, previous assessments of the hydroclimate in this region have mainly focused on the simulation of river runoff, whereas the response of vegetation to climate change and the resulting hydrological effects have not been fully considered. Forestry management and the ecological restoration of watersheds require a clear understanding of the hydrological effects of forest vegetation and its response to climate change. To study the hydrological effects of climate change on vegetation and the surface water balance and to reveal the major factors controlling the spatial variation of the forest-runoff relationship at the basin scale, we need to study the carbon-water cycle and the vegetation dynamics within a basin under a unified dynamic framework.

A realistic assessment of spatiotemporal variability in the terrestrial water budget requires models that mechanistically link vegetation dynamics and hydrological processes. The land surface schemes used in climate models are among the candidate models that meet this requirement (Gerten et al., 2004). Land surface models quantitatively describe the transfer of energy, mass and momentum between the atmosphere and the vegetated surface of the Earth (Sellers et al., 1986, 1996; Xue et al., 1991). The third-generation land surface models incorporate a realistic canopy photosynthesis-conductance model to describe the simultaneous transfer of $\mathrm{CO}_{2}$ and water vapor in the soil-vegetation-atmosphere continuum and their response to climate change (Sellers et al., 1997; Zhan et al., 2003; Dan et al., 2007; Peng \& Dan, 2015). The third-generation land surface models are coupled with dynamic vegetation models to simulate the interaction and feedback between vegetation and climate (Cox et al., 2000; Bonan et al., 2003; Cowling et al., 2009; Zeng et al., 2018). Whereas the earlier land surface models mainly considered the vertical transfer of soil water within the soil and canopy. The models ignore the horizontal heterogeneity of soil moisture and the subsequent impacts of this heterogeneity on evapotranspiration and runoff (Stieglitz et al., 1996).

Topography plays a key part in the non-uniform spatial distribution of soil moisture (Beven \& Kirkby, 1979; Beven, 2000). The topographic index model TOPMODEL has provided a useful tool to reflect the effects of topography on the soil moisture content and simple solutions to analytically calculate hydrological processes (Stieglitz et al., 1996). Previous work has proposed some simplified and effective coupling schemes to couple TOPMODEL with the current popular land surface models for use in land-atmosphere interaction studies at basin, regional or global scales (Stieglitz et al., 1996; Koster et al., 2000; Warrac et al., 2002; Gedney \& Cox, 2003; Douville, 2003; Niu et al., 2005; Deng \& Sun, 2012).

The simplified simple biosphere (SSiB) model has been widely used in global and regional climate studies (Xue et al., 1991). The revised version (SSiB2) can simulate the $\mathrm{CO}_{2}$ flux (Zhan et al., 2003). The SSiB4 model has been coupled with the Top-down Representation of Interactive Foliage and Flora Including Dynamics (TRIFFID) model (SSiB4/TRIFFID) to investigate the interactions between vegetation and climate and validated with $13 \mathrm{ob}-$ servational datasets with different climate and land cover conditions (Xue et al., 2006; Liu et al., 2019). SSiB4 and SSiB4/TRIFFID have been tested at a number of sites, but simulation studies at the basin scale have rarely been carried out.

We coupled the SSiB4/TRIFFID model with TOPMODEL (hereinafter referred to as SSiB4T/TRIFFID) and carried out long-term dynamic simulations of vegetation succession and the water balance under different climate scenarios for the Suomo river basin in the mountainous region of southwestern China. This study focused on: (1) the impact of vegetation succession on evapotranspiration and runoff; (2) the response of vegetation and the water balance to changes in climate; and (3) the role of climate in the spatial variation of forest-runoff relationships and the water use efficiency (WUE) of forest ecosystems.

\section{SSiB4T/TRIFFID coupled model}

\subsection{SSiB4/TRIFFID coupled model}

The original SSiB model has eight prognostic physical state variables: the canopy temperature, the surface soil temperature and the deep layer temperature, the canopy 
interception water store, the ground interception water store and three soil moisture wetness variables in the three soil layers. The sensible heat flux and latent heat flux are calculated as diagnostic variables. The SSiB4 model was developed by incorporating a realistic canopy photosynthesis-conductance model into the SSiB model (Zhan et al., 2003). TRIFFID describes how the carbon density of vegetation and the fractional coverage of a given plant functional type (PFT) are updated based on the carbon balance of that PFT and on competition with other PFTs based on the Lotka-Volterra approach (Cox et al., 2001). In the SSiB4/TRIFFID coupled model, the SSiB4 model provides estimates of the net plant photosynthesis assimilation rate, autotrophic respiration and other surface conditions for TRIFFID. TRIFFID then calculates vegetation parameters such as the plant height and leaf area index (LAI) for the SSiB4 model. The SSiB4/TRIFFID model includes bare land and categorizes vegetation into broadleaf trees, needleleaf trees, C3 grasses, C4 plants, shrubs and tundra dwarf shrubs (Xue et al., 2006; Zhang et al., 2015; Liu et al., 2019).

\subsection{TOPMODEL}

TOPMODEL uses a simple analytical solution for the basin to solve the local groundwater table depth $z_{i}$ at any point $i$ relative to the mean groundwater table depth over the basin $\bar{z}$ and a relationship between $\bar{z}$ and the subsurface flow (base flow) $Q_{b}$ (Sivapalan et al., 1987):

$$
\begin{aligned}
& z_{i}=\bar{z}+\frac{1}{f}\left(\bar{\lambda}-\ln \frac{a_{i}}{\tan \beta_{i}}\right) ; \\
& Q_{b}=\frac{K_{s x}(z=0)}{f} e^{-\bar{\lambda}} e^{-f \bar{z}},
\end{aligned}
$$

where $a_{i}$ is the upslope area drained per unit contour length, $\beta_{i}$ is local surface topographic slope, $\lambda=\ln \frac{a_{i}}{\tan \beta_{i}}$ is the local topographic index at point $i, \bar{\lambda}$ is the mean topographic index over the basin, $f$ is the decay factor in the exponential law, $K_{s x}(z=0)$ is the lateral saturated hydraulic conductivity at the soil surface.

\subsection{Incorporation of the TOPMODEL equations into the SSiB4/TRIFFID model}

In TOPMODEL, lateral soil saturated hydraulic conductivity is assumed to decline with depth exponentially according to the Beven's assumption (Beven \& Kirkby, 1979; Sivapalan et al., 1987). But in SSiB4/TRIFFID, vertical saturated soil hydraulic conductivity is taken as constant from soil surface to the soil bottom. After the constant vertical soil saturated hydraulic conductivity in the original SSiB4/TRIFFID has been replaced by the exponential law in TOPMODEL, the baseflow can be expressed as (Chen \& Kumar, 2001; Niu et al., 2005):

$$
Q_{b}=\frac{\alpha K_{s z}(z=0)}{f} e^{-\bar{\lambda}} e^{-f \bar{z}}
$$

where $\alpha$ is the anisotropic factor, $K_{s z}(z=0)$ is the vertical saturated hydraulic conductivities at the soil surface.

The analytic form of TOPMODEL equations are incorporated into the SSiB4/TRIFFID model according to a simplified incorporation scheme in which the study region is divided into saturated and unsaturated zones (Stieglitz et al., 1996; Gedney \& Cox, 2003; Niu et al., 2005). Soil moisture heterogeneity is represented by saturated zone (Stieglitz et al., 1996). The fraction of the basin that is saturated at the surface (the water table at or above the surface) $F_{\text {sat }}$ can be derived by integrating Eq. (1). Niu et al. (2005) proposed a SIMTOP to parameterize the saturated fraction as:

$$
F_{s a t}=F_{\max } e^{-C_{s}(\lambda-\bar{\lambda})}=F_{\max } e^{-C_{s} f \bar{z}},
$$

where $C_{s}$ is a coefficient that can be derived by fitting the exponential function to the discrete cumulative distribution function of the topographic index and $F_{\max }$ is the maximum saturated fraction for a whole basin.

Rainfall at saturation region forms saturated runoff and does not infiltrate into soil. The scheme proposed by Stieglitz et al. (1996) is used to estimate the mean groundwater table depth $\bar{z}$ according to the average soil moisture of each layer provided by the SSiB4/TRIFFID. The baseflow $Q_{b}$ calculated using Eq. (2b) is extracted from the soil layers containing the groundwater table or located below the groundwater table (Niu et al., 2005; Deng \& Sun, 2012) to maintain the water balance and update the soil moisture content in the SSiB4/TRIFFID.

\section{Suomo river basin and configurations of experiments}

\subsection{Suomo river basin and data}

The Suomo river is located in a mountainous region of southwestern China, extending from about $31-33^{\circ} \mathrm{N}$ and $102-103^{\circ} \mathrm{E}$ (Figure 1). The altitude ranges from about 2300 to $5000 \mathrm{~m}$ with a mean altitude of $4000 \mathrm{~m}$. Two-thirds of the drainage area is located in Maerkang County and onethird in Hongyuan County. The Maerkang meteorological station is located in the basin and the Hongyuan meteorological station is located outside the basin. The mean annual precipitation, which is the area-weighted mean of the data from these two stations from 1961 to 1987 is $777.6 \mathrm{~mm} \mathrm{yr}^{-1}$ and the mean annual depth of the total runoff is $596.6 \mathrm{~mm} \mathrm{yr}^{-1}$. The forcing conditions required by modeling are the downward shortwave and long wave radiation, the air temperature, precipitation, vapor pressure and wind speed. The Princeton global forcing dataset (Sheffield et al., 2006) from January 1, 1983 to December 31,1987 is used as the forcing conditions for this study. The spatial resolution is $1 \times 1^{\circ}$ and the temporal resolution is $3 \mathrm{~h}$. The forcing dataset is produced by averaging the data over two grid points $\left(31.5^{\circ} \mathrm{N}, 102.5^{\circ} \mathrm{E}\right.$ and $32.5^{\circ}$ $\mathrm{N}, 102.5^{\circ} \mathrm{E}$ ) in the basin. The Maerkang meteorological station is $2600 \mathrm{~m}$ above sea-level and the mean annual 
temperature from 1983 to 1987 is $8.6^{\circ} \mathrm{C}$. The altitude of the Hongyuan County meteorological station is $3500 \mathrm{~m}$ and the mean annual temperature from 1983 to 1987 is $1.9^{\circ} \mathrm{C}$. The mean annual temperature of the two stations is $4.6^{\circ} \mathrm{C}$. The mean annual reanalysis near-surface temperature from 1983 to 1987 is $5.0^{\circ} \mathrm{C}$. The mean annual reanalysis precipitation from 1983 to 1987 is $686.3 \mathrm{~mm} \mathrm{yr}^{-1}$, less than the measured precipitation of $749.3 \mathrm{~mm} \mathrm{yr}^{-1}$ at Maerkang station. The reanalysis precipitation is lower than that at Maerkang station in July and September and the difference between the reanalysis and measured precipitation at Maerkang station is small in the other months.

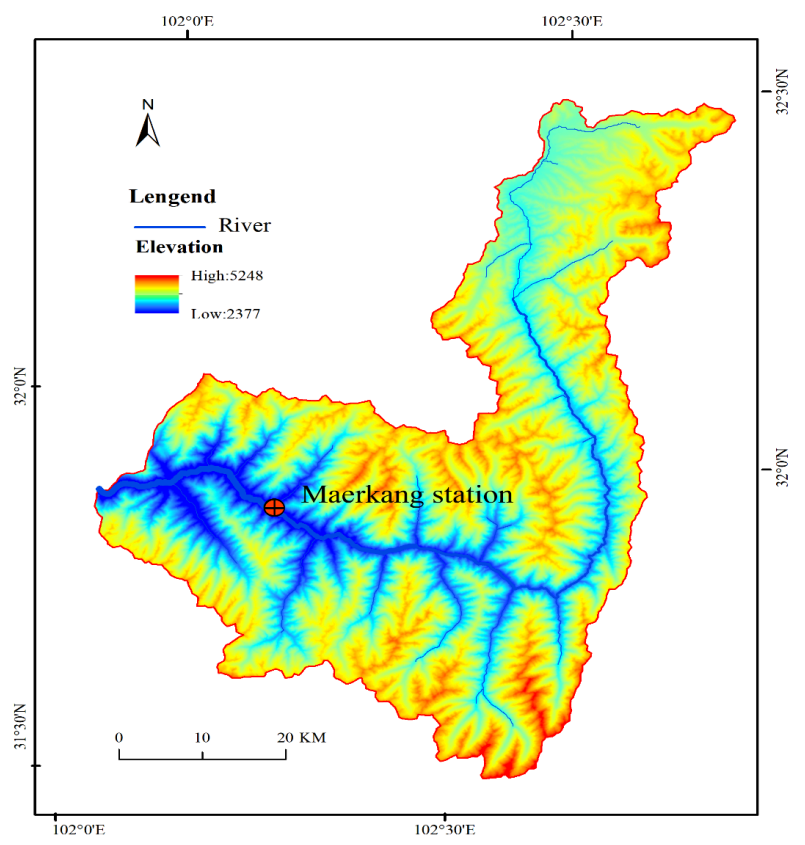

Figure 1. Sketch map of Suomo river basin

\subsection{Climate scenarios and configurations of experiments}

Six long-term dynamic simulations are run for vegetation succession and the water-carbon balances using the coupled model SSiB4T/TRIFFID (Table 1). In the first run (represented by $\mathrm{T}$ ), the five-year forcing data for the Suomo river basin is repeatedly run 120 times for a total of 600 consecutive years. The results from this run are used as a control for comparison with the outputs from later runs. To simulate the sensitivity of vegetation and the carbon-water balance to changes in climate, the scenarios are derived by simply adding the changes in temperature and precipitation to the original forcing data from 1983 to 1987 for each calculation step (e.g., in scenarios with $2{ }^{\circ} \mathrm{C}$ increase, the input temperature $t_{i}$ will be $t_{i}+2{ }^{\circ} \mathrm{C}$ ). The climate scenario is based on the change factor method (Arnell, 2003; Diaz-Nieto \& Wilby, 2005), which can be used effectively in sensitive and vulnerable areas (Minville et al., 2008; Dan et al., 2012), although it has the disadvantage that it cannot change the spatial variability (Minville et al., 2008; Diaz-Nieto \& Wilby, 2005).
Considering that the most prominent feature of the vertical climatic zonation is that the temperature increases as the altitude decreases, in the second experiment the input temperature of each calculation step is increased by $2{ }^{\circ} \mathrm{C}$ (represented by $\left.(\mathrm{T}+2)\right)$. In the third run, the input temperature and precipitation of each calculation step are increased by $2{ }^{\circ} \mathrm{C}$ and $20 \%$, respectively, (represented by $[\mathrm{T}+2,(1+20 \%) \mathrm{P}])$. As the altitude continues to decrease, temperature and precipitation generally further increase. In the fourth run, the input temperature and precipitation of each calculation step are increased by $5{ }^{\circ} \mathrm{C}$ and $40 \%$, respectively (represented by $[\mathrm{T}+5,(1+40 \%) \mathrm{P}])$. To facilitate the comparison between the simulated and measured runoff, in addition to the reanalysis of the precipitation data used in the simulation, the daily precipitation data for Maerkang station is evenly distributed between each calculation step in the simulation. In the fifth and sixth runs, the daily precipitation data for Maerkang station from 1983 to 1987 is divided by eight to replace the reanalysis precipitation in each step. In the fifth run, the temperature of each calculation step is the same as in T (represented by $\mathrm{PT}$ ). In the sixth run, the temperature of each calculation step is reduced by $1{ }^{\circ} \mathrm{C}$ (represented by PT-1).

Envionment $\mathrm{CO}_{2}$ content is assigned to $380 \times 10^{-6}$. The leaf drop threshold temperature is adjusted to $2{ }^{\circ} \mathrm{C}$ for broadleaf trees (the original leaf drop threshold temperature in the TRIFFID model is $0{ }^{\circ} \mathrm{C}$ ) to produce more significant seasonal variations. For the other PFTs, the original leaf drop threshold temperatures in the TRIFFID model are used: $-30^{\circ} \mathrm{C}$ for needleleaf trees, $-20^{\circ} \mathrm{C}$ for $\mathrm{C} 3$ and $\mathrm{C} 4$ grasses and $-30^{\circ} \mathrm{C}$ for shrubs (including tundra shrubs). The leaf drop threshold moisture factor is set to 0.2 for all PFTs and the initial fractional coverage of each vegetation type is set to 0.01 . The topographic indexes are calculated using the data from digital elevation model of the Shuttle Radar Topography Mission (United States Geological Survey, 2003). The spatial resolution is about $90 \times 90 \mathrm{~m}$. Based on the cumulative topographic index distribution function of the Suomo basin, $F_{\max }$ and $C_{s}$ are

Table 1. Summary of the experimental designs

\begin{tabular}{|l|l|l|}
\hline Treatment & \multicolumn{1}{|c|}{ Test description } & $\begin{array}{l}\text { Precipitation } \\
\text { type }\end{array}$ \\
\hline $\mathrm{T}$ & Control run & $\begin{array}{l}\text { Reanalysis } \\
\text { precipitation }\end{array}$ \\
\hline$(\mathrm{T}+2)$ & $\begin{array}{l}\text { Temperature increase by } 2{ }^{\circ} \mathrm{C} \text { for } \\
\text { each step }\end{array}$ & $\begin{array}{l}\text { Reanalysis } \\
\text { precipitation }\end{array}$ \\
\hline $\begin{array}{l}{[\mathrm{T}+2,} \\
(1+20 \%) \\
\mathrm{P}]\end{array}$ & $\begin{array}{l}\text { Increase in temperature of } 2{ }^{\circ} \mathrm{C} \text { and } \\
\text { increase in precipitation by } 20 \% \text { for } \\
\text { each step }\end{array}$ & $\begin{array}{l}\text { Reanalysis } \\
\text { precipitation }\end{array}$ \\
\hline $\begin{array}{l}{[\mathrm{T}+5,} \\
(1+40 \%) \\
\mathrm{P}]\end{array}$ & $\begin{array}{l}\text { Increase in temperature by } 5^{\circ} \mathrm{C} \\
\text { and increase in precipitation by } \\
40 \% \text { for each step }\end{array}$ & $\begin{array}{l}\text { Reanalysis } \\
\text { precipitation }\end{array}$ \\
\hline $\mathrm{PT}$ & Control run & $\begin{array}{l}\text { Measured } \\
\text { precipitation }\end{array}$ \\
\hline $\mathrm{PT}-1$ & $\begin{array}{l}\text { Temperature reduced by } 1{ }^{\circ} \mathrm{C} \text { for } \\
\text { each step }\end{array}$ & $\begin{array}{l}\text { Measured } \\
\text { precipitation }\end{array}$ \\
\hline
\end{tabular}


derived by exponential fitting $\left(F_{\max }=0.4\right.$ and $C_{s}=0.45$ ) (Deng \& Sun, 2012). A value of $K_{s}(z=0)=2.2 \times 10^{-3} \mathrm{~m} \mathrm{~s}^{-1}$ is used as the soil saturated hydraulic conductivity at the surface, the anisotropic factor $\alpha$ is 75 and decay factor $f$ is $2 \mathrm{~m}^{-1}$ (Deng \& Sun, 2012). The soil thicknesses for three layers are $0.02 \mathrm{~m}$ (surface layer), $1.0 \mathrm{~m}$ (root layer) and $2.0 \mathrm{~m}$ (deep layer).

\section{Results and analysis}

\subsection{Temporal evolution of vegetation fraction and leaf area index}

Figure $2 \mathrm{a}-2 \mathrm{~b}$ shows the evolution of four major vegetation fractions during the 600 simulation years modeled by the $\mathrm{T}$ run and $[\mathrm{T}+5,(1+40 \%) \mathrm{P}]$ run. During the early time period of model integration, the vegetation fractions change from a dominance of C3 grasses to a dominance of tundra shrubs and then gradually approach equilibrium after about the 400th simulation year.

The fractional coverage of C3 grass initially increases rapidly, but after it reaches a peak value in the sixth simulation year it decreases rapidly with an increase in the fractional cover of tundra shrubs. The fractional coverage of tundra shrubs reaches a peak value in about the 25 th simulation year and then decreases with the increase in the fractional cover of trees. The fraction of needleleaf trees surpasses the fraction of tundra shrubs after 200 simulation years. Needleleaf trees and broadleaf trees are dominant in the basin after 400 simulation years. The maximum fractional coverage of $\mathrm{C} 3$ grass increases as
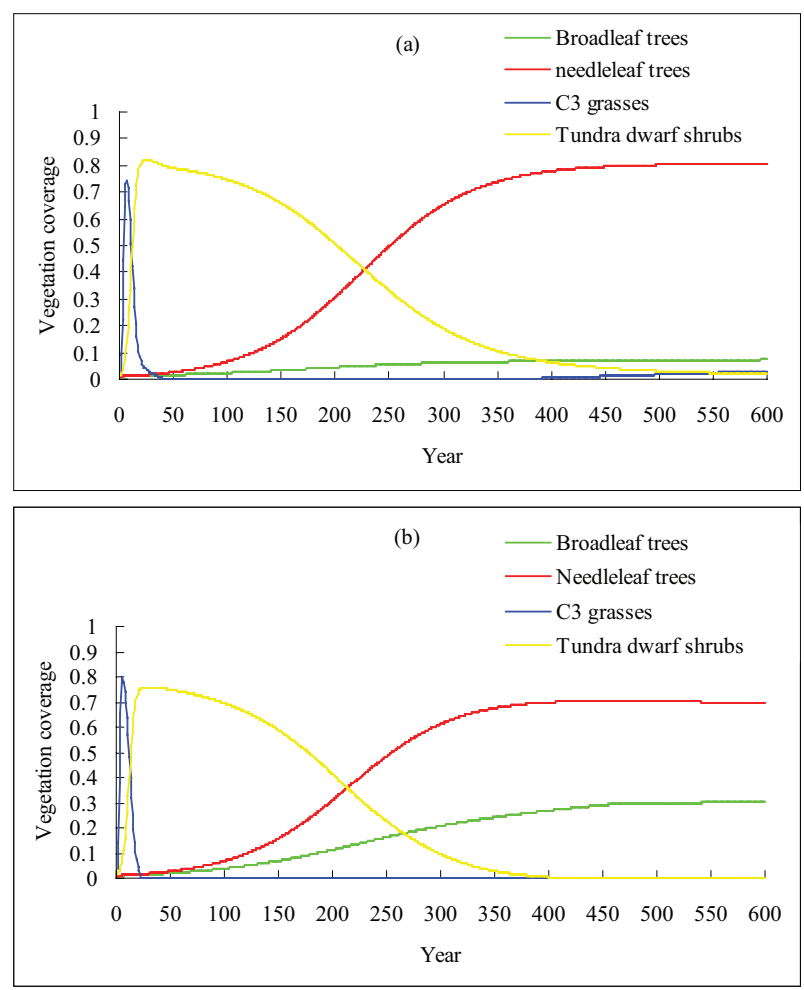

Figure 2. Temporal evolution of vegetation fractions. Results of experiments: (a) T; and (b) $[\mathrm{T}+5,(1+40 \%) \mathrm{P}]$

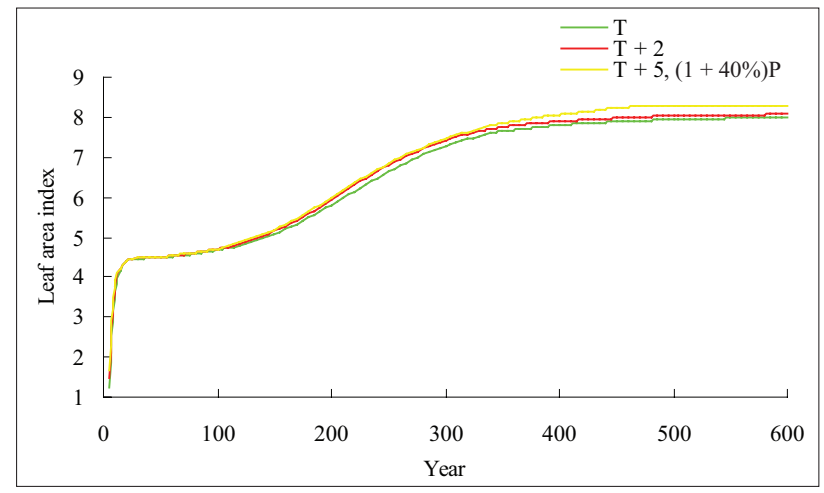

Figure 3. Temporal changes in the annual LAI

the temperature increases: exp. T, 0.74; exp. $(\mathrm{T}+2), 0.77$; and exp. $[\mathrm{T}+5,(1+40 \%) \mathrm{P}], 0.80$. The maximum fractional coverage of tundra shrubs decreases as the temperature increases: exp. T, 0.82; exp. $(\mathrm{T}+2), 0.80$; and exp. [ $\mathrm{T}+5$, $(1+40 \%) \mathrm{P}], 0.76$. The maximum fractional coverage of needleleaf trees decreases as the temperature increases: exp. T, 0.81; exp. $(\mathrm{T}+2), 0.79$; and exp. [T+5, $(1+40 \%) \mathrm{P}]$, 0.70 . The fractional coverage of broadleaf trees increases as the temperature increases: exp. T, 0.07; exp. (T+2), 0.13; and exp. $[\mathrm{T}+5,(1+40 \%) \mathrm{P}], 0.30$. The temporal evolution of the vegetation fractions produced by the PT run is the same as that simulated by the $\mathrm{T}$ run. The difference in temporal evolution of the vegetation fractions between the PT- 1 and PT run is very small.

Figure 3 shows the changes in the five-year average annual LAI modeled by the $\mathrm{T}$ run, $(\mathrm{T}+2)$ run and $[\mathrm{T}+5$, $(1+40 \%) \mathrm{P}]$ run. The LAI of the basin increases as the vegetation fractions in the basin evolve. After the 450th simulation year, the annual LAI reaches equilibrium status with values of about 8.0 in the $\mathrm{T}$ run, 8.1 in the $(\mathrm{T}+2)$ run and 8.3 in the $[\mathrm{T}+5,(1+40 \%) \mathrm{P}]$ run. As temperature increases, the coniferous forest evolves into coniferous and broadleaf mixed forest and the annual LAI of the basin increases.

\subsection{Changes in the annual evapotranspiration and runoff depth with the evolution of vegetation}

\subsubsection{Temporal changes in evapotranspiration and runoff depth}

The simulated annual runoff depth and evapotranspiration are averaged every five simulation years (Figure 4). Figure $4 \mathrm{a}$ shows the annual changes in runoff depth in the PT-1, PT, T, $(\mathrm{T}+2)$ and $[\mathrm{T}+5,(1+40 \%) \mathrm{P}]$ runs and Figure $4 \mathrm{~b}$ shows the changes in the corresponding annual evapotranspiration of the basin. In the PT run, as the vegetation evolves temporally from C3 grasses into tundra shrubs, the annual runoff of the basin decreases rapidly with an increase in the fractional coverage of tundra shrubs. The annual runoff is at a minimum when the coverage of tundra shrubs is at a maximum. As the vegetation evolves temporally from tundra shrubs into forest, the annual runoff continues to increase steadily and remains stable after the 400th simulation year. The temporal evolution of the annual evapotranspiration of the basin is the 
opposite of the annual runoff. The annual evapotranspiration initially increases and reaches a maximum value when the fractional coverage of the tundra shrubs reaches its peak value and then decreases with the decrease in the fractional coverage of the tundra shrubs and the increase in the fractional coverage of forest.

The change in the annual runoff depth and evapotranspiration with the evolution of vegetation in the control experiment $\mathrm{T}$ is consistent with the changes in the PT run. Although the input temperature is the same in the $\mathrm{T}$ and the PT runs, the precipitation input in the PT run is the data measured at Maerkang station, which is higher than the reanalysis precipitation. The evapotranspiration in the PT run is slightly higher than that in the T run when forests are dominant in the basin (Figure $4 \mathrm{~b}$ ). The additional precipitation in exp. PT compared to exp. T mainly increases runoff (Figure 4a).

The changes of the annual runoff depth and evapotranspiration with the temporal evolution of vegetation in the PT-1 run are consistent with the changes in the PT run. In PT-1 run, the temperature is reduced by $1{ }^{\circ} \mathrm{C}$ compared to PT run. The evapotranspiration in the PT-1 run is significantly reduced and the annual runoff depth is clearly increased compared with the results in the PT run.

The annual runoff depth decreases and the evapotranspiration increases significantly in the $(\mathrm{T}+2)$ run compared with the control experiment T. Although the annual runoff depth increases and evapotranspiration decreases with the increase in the fractional coverage of forest in the $(\mathrm{T}+2)$ run, the increase in the runoff depth and the decrease in evapotranspiration are less than those produced by the control experiment $\mathrm{T}$.
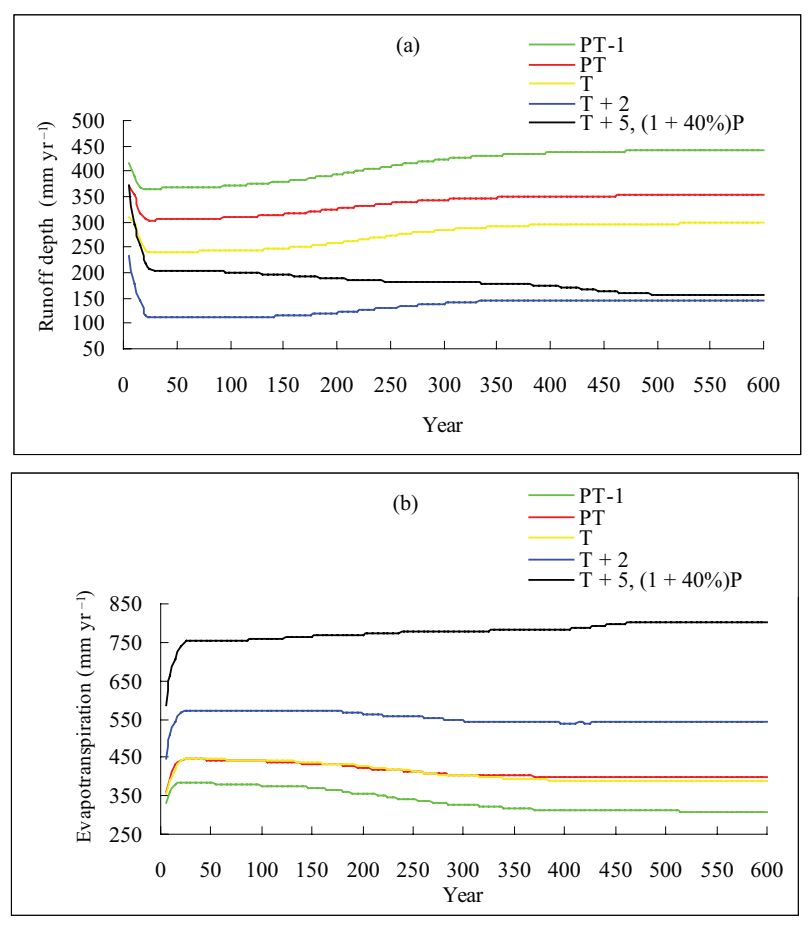

Figure 4. Temporal changes in (a) the annual runoff depth; and (b) the annual evapotranspiration
The annual runoff depth of the basin decreases rapidly and then continues to decrease with the increase in the fractional coverage of forests and no longer increases in the $[\mathrm{T}+5,(1+40 \%) \mathrm{P}]$ run. Unlike control run and $(\mathrm{T}+2)$ run, $[\mathrm{T}+5,(1+40 \%) \mathrm{P}]$ run produces that evapotranspiration reaches a maximum value and the annual runoff is at a minimum when forests dominate the basin. From the control run to the $[\mathrm{T}+5,(1+40 \%) \mathrm{P}]$ run, compared with the tundra shrubs, the presence of forests to increase runoff changes to increase evapotranspiration and reduce runoff depth.

\subsubsection{Effects of vegetation and climate on annual runoff depth and evapotranspiration}

C3 grasses dominate the basin during the period of the $6-10$ th simulation years (hereinafter the first period). Tundra shrubs dominate the basin during the period of the 21st-25th simulation years (hereinafter the second period), whereas forests dominate in the basin during the period of last five simulation years (hereinafter the third period). The simulations of these three periods are used to analyze the effects of changes in vegetation and climate on the surface water balance of the basin. Table 2 shows the five-year averaged annual precipitation $\mathrm{P}\left(\mathrm{mm} \mathrm{yr}^{-1}\right)$, annual evapotranspiration ET $\left(\mathrm{mm} \mathrm{yr}^{-1}\right)$ and annual runoff depth $\mathrm{R}$ ( $\mathrm{mm} \mathrm{yr}^{-1}$ ) for these three periods.

Table 2. Water balance of the basin during the three time periods

\begin{tabular}{|c|c|c|c|c|}
\hline \multirow{2}{*}{ Treatment } & \multirow{2}{*}{ Variable } & \multicolumn{3}{|c|}{ Simulation year } \\
\cline { 3 - 5 } & & $\begin{array}{c}\text { the 6-10th } \\
\text { years }\end{array}$ & $\begin{array}{c}\text { the 21st- } \\
\text { 25th years }\end{array}$ & $\begin{array}{c}\text { the 596th- } \\
\text { 600th years }\end{array}$ \\
\hline \multirow{3}{*}{ PT-1 } & P & 749.3 & 749.3 & 749.3 \\
& ET & 332.1 & 382.7 & 308.4 \\
& $\mathrm{R}$ & 441.2 & 366.8 & 441.2 \\
\hline & $\mathrm{P}$ & 749.3 & 749.3 & 749.3 \\
$\mathrm{PT}$ & $\mathrm{ET}$ & 393.6 & 444.6 & 397.0 \\
& $\mathrm{R}$ & 355.7 & 304.8 & 352.6 \\
\hline & $\mathrm{P}$ & 686.3 & 686.3 & 686.3 \\
$\mathrm{~T}$ & $\mathrm{ET}$ & 388.5 & 445.3 & 388.1 \\
& $\mathrm{R}$ & 297.8 & 241.0 & 298.0 \\
\hline & $\mathrm{P}$ & 686.3 & 686.3 & 686.3 \\
$(\mathrm{~T}+2)$ & $\mathrm{ET}$ & 507.2 & 574.1 & 539.6 \\
& $\mathrm{R}$ & 179.0 & 112.1 & 146.6 \\
\hline [T+2, & $\mathrm{P}$ & 823.5 & 823.5 & 823.5 \\
$(1+20 \%)$ & $\mathrm{ET}$ & 516.0 & 587.0 & 548.6 \\
$\mathrm{P}]$ & $\mathrm{R}$ & 307.1 & 236.5 & 274.9 \\
\hline$[\mathrm{T}+5$, & $\mathrm{P}$ & 960.8 & 960.8 & 960.8 \\
$(1+40 \%)$ & $\mathrm{ET}$ & 665.9 & 753.2 & 802.9 \\
$\mathrm{P}]$ & $\mathrm{R}$ & 294.5 & 207.7 & 157.9 \\
\hline
\end{tabular}

In the mountainous region of southwestern China, annual runoff coefficient decreases as altitude decreases (Cheng, 1991). Modeled annual runoff coefficient decreases as temperature increases. During the period of last five simulation years, from PT-1 run to $[\mathrm{T}+5,(1+40 \%) \mathrm{P}]$ run, Modeled annual runoff coefficient changes from 0.58 to 0.16 . Although the modeled runoff is lower than the 
observed runoff, the changes of annual runoff coefficient with temperature increase (altitude decrease) are consistent with observations.

In PT-1, PT, $\mathrm{T},(\mathrm{T}+2)$ and $[\mathrm{T}+2,(1+20 \%) \mathrm{P}]$ run, the annual evapotranspiration of the basin is highest during the second period. In $[\mathrm{T}+5,(1+40 \%) \mathrm{P}]$ run, the annual evapotranspiration becomes highest and the runoff depth is lowest during the third period. From the control run $\mathrm{T}$ to $(\mathrm{T}+2)$ run, the evapotranspiration of the three plant types increases by $30.6 \%$ (C3 grasses), $28.9 \%$ (tundra shrubs) and 39.0\% (forests), respectively. From the control run $\mathrm{T}$ to the $[\mathrm{T}+5,(1+40 \%) \mathrm{P}]$ run, the evapotranspiration of $\mathrm{C} 3$ grasses, tundra shrubs and forests increases by $69.1 \%, 71.4 \%$ and $106.9 \%$, respectively. From PT-1 run to PT run, the evapotranspiration of the three plant types increases by $18.5 \%, 16.2 \%$ and $28.7 \%$, respectively. Among three vegetation types evapotranspiration from the forests is most sensitive to changes in temperature.

The annual runoff depth in PT run, where the temperature is increased by $1.0^{\circ} \mathrm{C}$ relative to $\mathrm{PT}-1$ run is reduced by $14.8 \%$ (C3 grasses), by $16.9 \%$ (tundra shrubs) and by $20.1 \%$ (forests). The annual runoff depth in $(\mathrm{T}+2)$ run is reduced by $39.9 \%$ (C3 grasses), by $53.5 \%$ (tundra shrubs) and by $50.8 \%$ (forests). From the control run $\mathrm{T}$ to $[\mathrm{T}+2$, $(1+20 \%) \mathrm{P}]$ run, the annual runoff depth is increased by $3.1 \%$ (C3 grasses) and is reduced by $1.9 \%$ (tundra shrubs) and reduced by $7.8 \%$ (forests). An increase in precipitation of $20 \%$ can offset the increase in evapotranspiration when c3 grasses are dominant. This does not offset the increase in evapotranspiration when tundra shrubs and forests are dominant. From the control run $\mathrm{T}$ to $[\mathrm{T}+5,(1+40 \%)$ $\mathrm{P}]$ run, the annual runoff depth is reduced by $1.1 \%$ (C3 grasses), $13.8 \%$ (tundra shrubs) and $47.1 \%$ (forests), respectively.

The annual evapotranspiration in PT run, where there is an increase in precipitation of $9.2 \%$ relative to $\mathrm{T}$ run, increases slightly during the three time periods and the annual runoff depth increases by $19.7 \%$ (C3 grasses), by $26.5 \%$ (tundra shrubs ) and by $18.2 \%$ (forests). The annual evapotranspiration in the $[(\mathrm{T}+2),(1+20 \%) \mathrm{P}]$ run, an increase in precipitation by $20 \%$ relative to $(\mathrm{T}+2)$ run, increases the annual evapotranspiration by about $10 \mathrm{~mm}$ $\mathrm{yr}^{-1}$. If temperature remains unchanged, the evapotranspiration is not sensitive to changes in precipitation. An increase in precipitation has little effect on evapotranspiration and mainly increases runoff.

\subsubsection{Influence of vegetation and climate on the three components of evapotranspiration}

Figure $5 \mathrm{a}-5 \mathrm{c}$ show the responses of the three components of evapotranspiration (the canopy interception evaporation, transpiration and the soil evaporation) to the changes in vegetation and climate produced by the $\mathrm{T},(\mathrm{T}+2)$ and $[\mathrm{T}+5,(1+40 \%) \mathrm{P}]$ runs. For $\mathrm{T}$ run, transpiration reaches its maximum value during the second period and then decreases as the fractional coverage of forest increases. For $(\mathrm{T}+2)$ run, the transpiration increases slightly as the fractional coverage of forest increases and gradually reaches the maximum. For $[\mathrm{T}+5,(1+40 \%) \mathrm{P}]$ run, transpiration significantly increases as fractional coverage of forest increases. The forests intercept the most precipitation, followed by the shrubs and grasses. The canopy interception evaporation increases and as the vegetation evolves from C3 grasses to tundra shrubs and then to forests. Soil evaporation is significantly reduced as the vegetation evolves from grasses to tundra shrubs to forest. Transpiration and canopy interception evaporation increase with increasing temperature, but the increase in transpiration and canopy interception evaporation is significantly greater for forests than for tundra shrubs and C 3 grasses.

Table 3 shows the five-year average transpiration $\left(\mathrm{mm} \mathrm{yr}^{-1}\right)$, canopy interception evaporation $\left(\mathrm{mm} \mathrm{yr}^{-1}\right)$ and soil evaporation $\left(\mathrm{mm} \mathrm{yr}^{-1}\right)$ during the three periods
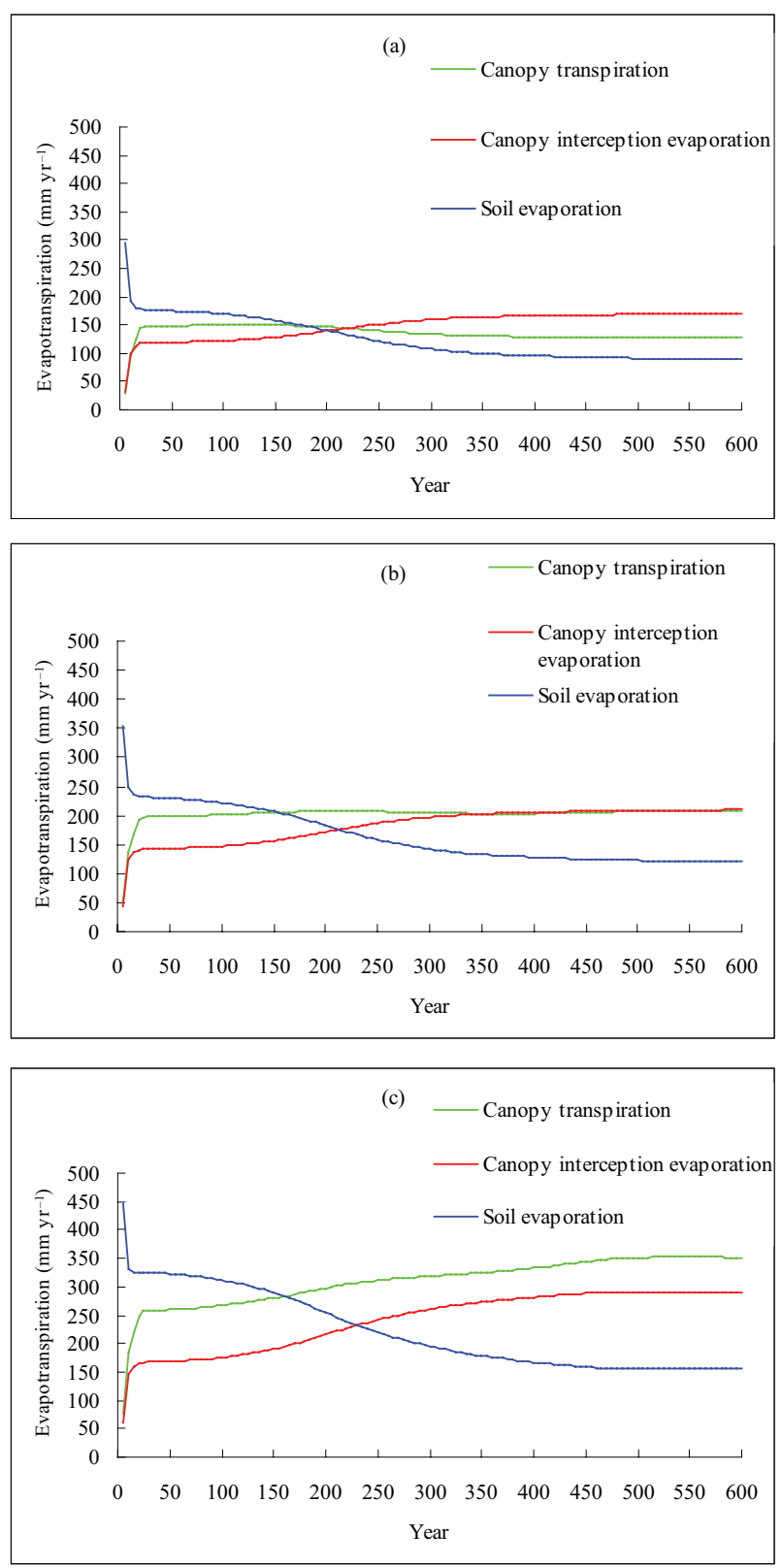

Figure 5. Temporal evolution of transpiration, canopy interception evaporation and soil evaporation: (a) Exp. T; (b) exp. $(\mathrm{T}+2)$; and (c) exp. [T+5, (1+40\%)P] 
of the six experimental simulations. For C3 grasses and tundra shrubs, soil evaporation accounts for the largest proportion of evapotranspiration in all runs. For forests, canopy interception evaporation accounts for the largest proportion of evapotranspiration in the control run $\mathrm{T}$. In $(\mathrm{T}+2)$ run, forest transpiration and canopy interception evaporation account for the about same proportion of evapotranspiration. In $[\mathrm{T}+5,(1+40 \%) \mathrm{P}]$ run, forest transpiration accounts for the largest proportion of evapotranspiration. The transpiration in the PT run is less than that in the T run, whereas the canopy interception evaporation is greater than that in the $\mathrm{T}$ run. The input precipitation in the PT run is higher than the reanalysis precipitation, and the daily precipitation is evenly distributed to each step, resulting in an increase in wet areas in the canopy and the canopy interception evaporation and a decrease in the transpiration from dry areas of the canopy. The evapotranspiration in the PT run is slightly higher than that in the $\mathrm{T}$ run (Figure $4 \mathrm{~b}$ ). Therefore the equal distribution of the daily precipitation to each calculation step affects the ratio of transpiration and canopy interception evaporation in canopy evapotranspiration, but has little effect on the simulation results for evapotranspiration.

Table 3. Transpiration $\left(\mathrm{E}_{d c}\right)$, canopy interception evaporation

$\left(\mathrm{E}_{w c}\right)$ and soil evaporation $\left(\mathrm{E}_{g s}\right)$ during the three periods

\begin{tabular}{|c|c|c|c|c|}
\hline \multirow{2}{*}{ Treatment } & \multirow{2}{*}{ Variable } & \multicolumn{3}{|c|}{ Simulation year } \\
\cline { 3 - 5 } & & $\begin{array}{c}\text { the 6-10th } \\
\text { years }\end{array}$ & $\begin{array}{c}\text { the 6-10th } \\
\text { years }\end{array}$ & $\begin{array}{c}\text { the 596th- } \\
\text { 600th years }\end{array}$ \\
\hline \multirow{3}{*}{ PT-1 } & $\mathrm{E}_{d c}$ & 68.5 & 110.9 & 86.4 \\
& $\mathrm{E}_{w c}$ & 105.5 & 133.2 & 153.9 \\
& $\mathrm{E}_{g s}$ & 157.2 & 137.6 & 68.7 \\
\hline \multirow{3}{*}{$\mathrm{PT}$} & $\mathrm{E}_{d c}$ & 83.1 & 120.9 & 108.4 \\
& $\mathrm{E}_{w c}$ & 133.6 & 156.2 & 206.3 \\
& $\mathrm{E}_{g s}$ & 175.5 & 165.9 & 81.3 \\
\hline \multirow{3}{*}{$\mathrm{T}$} & $\mathrm{E}_{d c}$ & 96.6 & 149.2 & 129.2 \\
& $\mathrm{E}_{w c}$ & 99.4 & 119.3 & 170.6 \\
& $\mathrm{E}_{g s}$ & 194.3 & 178.9 & 90.4 \\
\hline \multirow{2}{*}{$\mathrm{T}+2$} & $\mathrm{E}_{d c}$ & 136.3 & 198.2 & 208.0 \\
& $\mathrm{E}_{w c}$ & 123.2 & 143.4 & 211.3 \\
& $\mathrm{E}_{g s}$ & 248.9 & 234.3 & 122.1 \\
\hline \multirow{2}{*}{$\mathrm{T}+2}$, & $\mathrm{E}_{d c}$ & 133.4 & 194.7 & 203.6 \\
$(1+20 \%) \mathrm{P}]$ & $\mathrm{E}_{w c}$ & 127.2 & 147.4 & 220.5 \\
& $\mathrm{E}_{g s}$ & 253.5 & 242.8 & 122.9 \\
\hline \multirow{2}{*}{$\mathrm{T}+5}$, & $\mathrm{E}_{d c}$ & 185.3 & 258.7 & 353.1 \\
$(1+40 \%) \mathrm{P}]$ & $\mathrm{E}_{w c}$ & 146.7 & 168.1 & 293.0 \\
& $\mathrm{E}_{g s}$ & 334.7 & 327.4 & 157.8 \\
\hline
\end{tabular}

\subsection{Monthly runoff depth and evapotranspiration}

\subsubsection{Monthly runoff depth}

Figure 6 shows the five-year mean monthly runoff depth produced by PT-1, PT, T and [T+5, $(1+40 \%)$ P] runs during the three periods. Figure $6 \mathrm{a}-6 \mathrm{~d}$ compare the monthly runoff depth between the measured runoff depth and the simulations. The runoff depth is underestimated relative to the observations, especially before the rainy season. The biases are attributable to uncertainties in the climate input data, such as precipitation and overestimates of the evapotranspiration.

Figure 6a shows the results of the PT run. The monthly runoff depth is lowest when tundra shrubs are dominant. The monthly runoff depth when C3 grasses are dominant is similar to that when forests are dominant. Figure $6 \mathrm{~b}$ shows the results of the PT-1 run. The monthly runoff depth increases compared with the results of PT run as a result of the decrease in temperature by $1{ }^{\circ} \mathrm{C}$. The monthly runoff depth is still the lowest when tundra shrubs are dominant, but the highest monthly runoff depth is seen when forests are dominant.
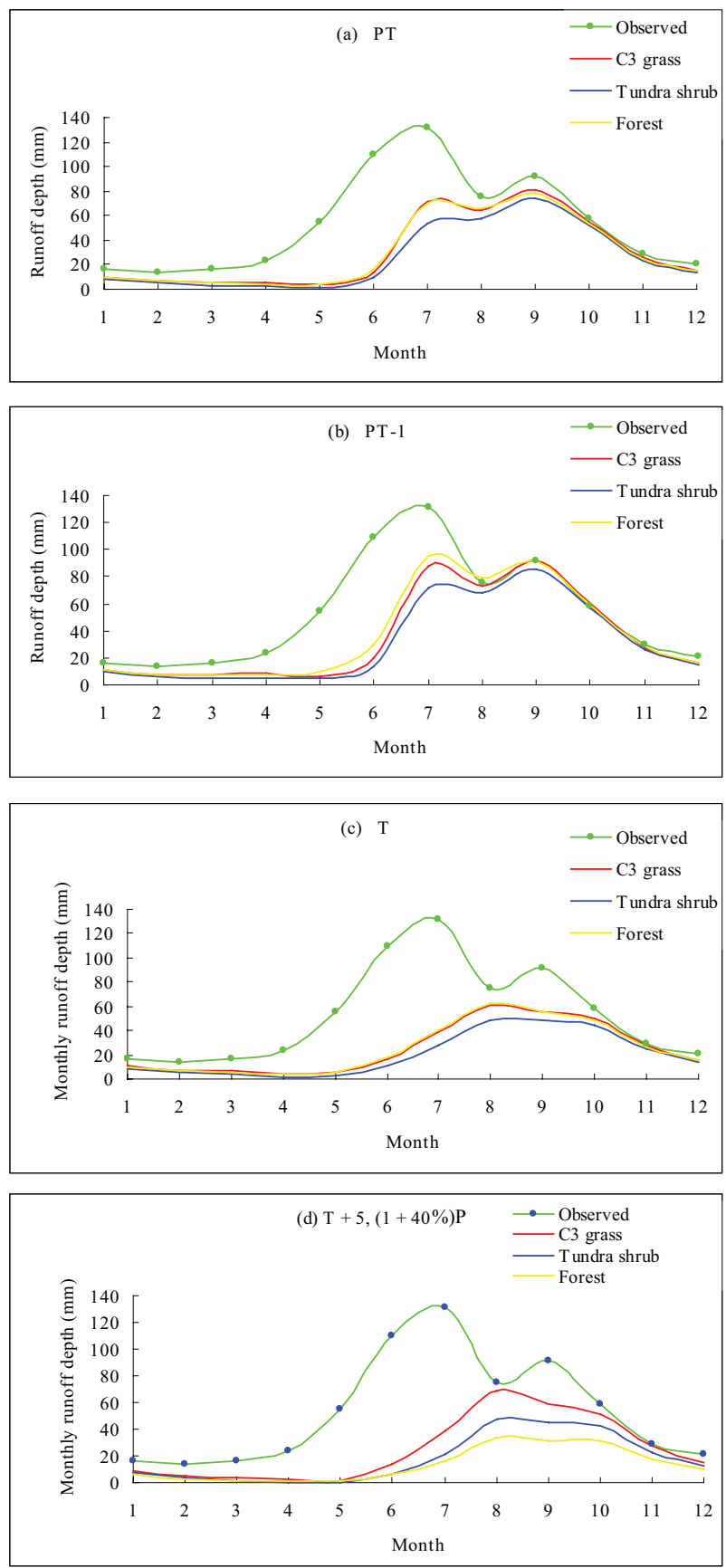

Figure 6. Five-year mean monthly runoff depth during the three periods: (a) PT run; (b) PT-1 run; (c) T run; and (d) $[\mathrm{T}+5,(1+40 \%) \mathrm{P}]$ run 
Figure $6 \mathrm{c}$ shows the results of the control run T. Because the reanalysis precipitation data is less than the measured precipitation at Maerkang station in July and September, the two peaks of monthly runoff in July and September are not produced. The monthly runoff depth is still the smallest when tundra shrubs are dominant. Figure $6 \mathrm{~d}$ shows the results of the $[\mathrm{T}+5,(1+40 \%) \mathrm{P}]$ run. The monthly runoff depth is highest when $\mathrm{C} 3$ grasses are dominant, followed by the monthly runoff depth when tundra shrubs are dominant. The lowest monthly runoff depth occurs when forests are dominant.
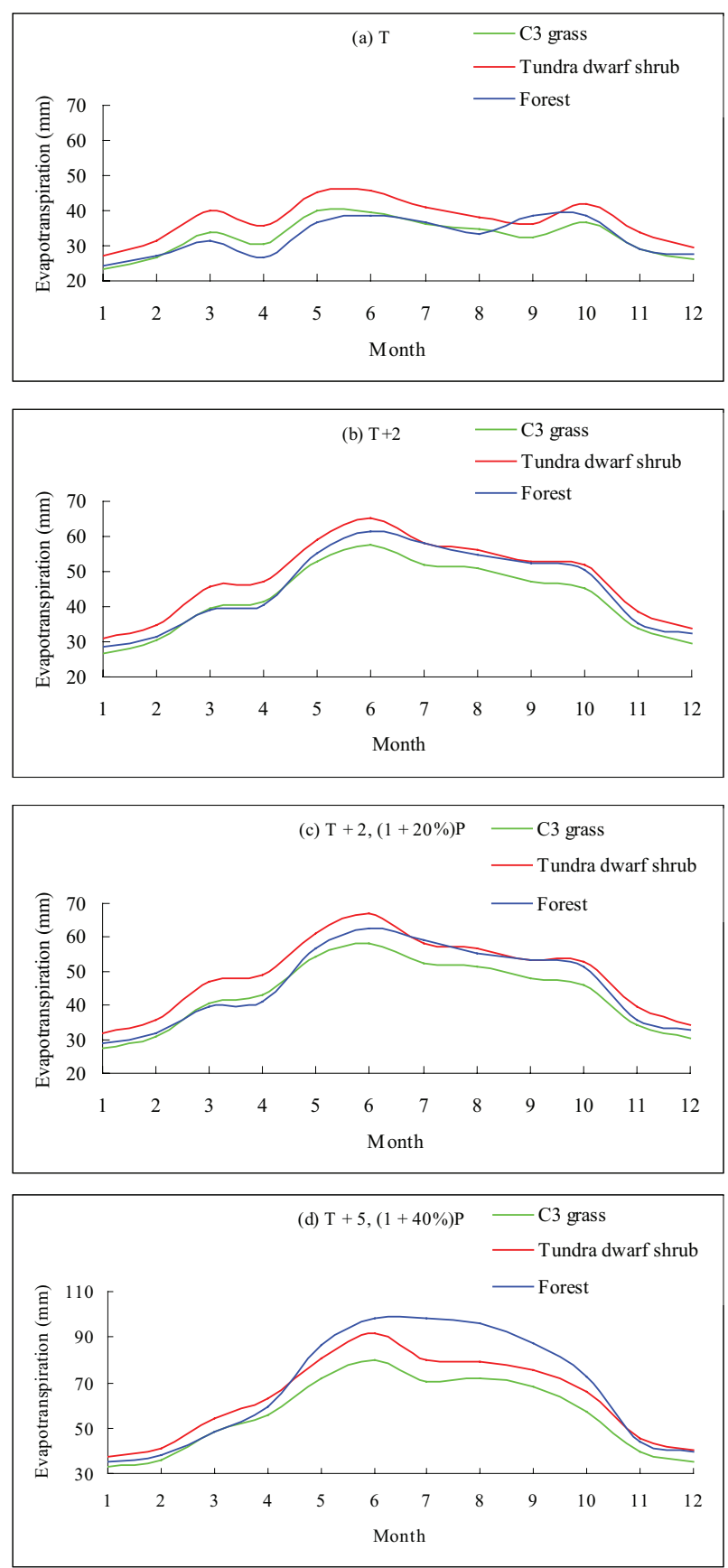

Figure 7. Five-year mean monthly evapotranspiration during the three periods: (a) $\mathrm{T}$ run; (b) $(\mathrm{T}+2)$ run;

(c) $[\mathrm{T}+2,(1+20 \%) \mathrm{P}]$ run; and $(\mathrm{d})[\mathrm{T}+5,(1+40 \%) \mathrm{P}]$ run

\subsubsection{Monthly evapotranspiration of the basin}

Figure 7 shows the five-year mean monthly evapotranspiration during the three periods produced by $\mathrm{T},(\mathrm{T}+2)$, $[\mathrm{T}+2,(1+20 \%) \mathrm{P}]$ and $[\mathrm{T}+5,(1+40 \%) \mathrm{P}]$ runs. For the control experiment $\mathrm{T}$ in Figure 7a, the monthly evapotranspiration of tundra shrubs is higher than that of $\mathrm{C} 3$ grasses and forests, except in September. For the $(\mathrm{T}+2)$ run, the monthly evapotranspiration of forests is lower than that of C3 grasses during the dry season. The monthly evapotranspiration of forests during the dry season very similar to that of tundra shrubs. However, it is lower than that of tundra shrubs during the rainy season (Figure $7 \mathrm{~b}$ ). The monthly evapotranspiration produced by $[\mathrm{T}+2,(1+20 \%)$ $\mathrm{P}]$ run is very similar to that in $(\mathrm{T}+2)$ run (Figure $7 \mathrm{c}$ ). For $[\mathrm{T}+5,(1+40 \%) \mathrm{P}]$ run, the monthly evapotranspiration during the three periods increases significantly (Figure $7 \mathrm{~d}$ ). The mean monthly evapotranspiration of forests is significant higher than that of tundra shrubs from May to October and is slightly lower than that of tundra shrubs during the dry season.

\subsection{LAI, net primary productivity and WUE of forest ecosystems}

Figure 8 shows the monthly LAI averaged over the last five years produced by $\mathrm{T},(\mathrm{T}+2),[\mathrm{T}+2,(1+20 \%) \mathrm{P}]$ and $[\mathrm{T}+5$, $(1+40 \%) \mathrm{P}]$ runs. The forest LAI increases with temperature in the summer half-year. The LAI produced by $(\mathrm{T}+2)$, $[\mathrm{T}+2,(1+20 \%) \mathrm{P}]$ and $[\mathrm{T}+5,(1+40 \%) \mathrm{P}]$ runs in the winter half-year is lower than that produced by the control run $\mathrm{T}$. This is because the fractional coverage of broadleaf trees increases with temperature and the leaf drop threshold temperature for broadleaf trees is set to $2{ }^{\circ} \mathrm{C}$. In winter, the canopy temperature drops below $2{ }^{\circ} \mathrm{C}$ and reduces the LAI of broadleaf trees. Comparing the LAI produced by $[\mathrm{T}+2,(1+20 \%) \mathrm{P}]$ run with $(\mathrm{T}+2)$ run, an increase in precipitation of $20 \%$ has a slight effect on the LAI.

Figure 9a shows the monthly net primary productivity (NPP) averaged over the last five years produced by exp. T, exp. $(\mathrm{T}+2)$ and exp. $[\mathrm{T}+5,(1+40 \%) \mathrm{P}]$. The NPP of forests increases with temperature in the summer halfyear. The annual NPP averaged over the last five simulated years produced by exp. T, $(\mathrm{T}+2)$ and $[\mathrm{T}+5,(1+40 \%)$ $\mathrm{P}]$ is $1052.0,1093.6$ and $1199.5 \mathrm{gC} \mathrm{m}^{-2} \mathrm{yr}^{-1}$ respectively.

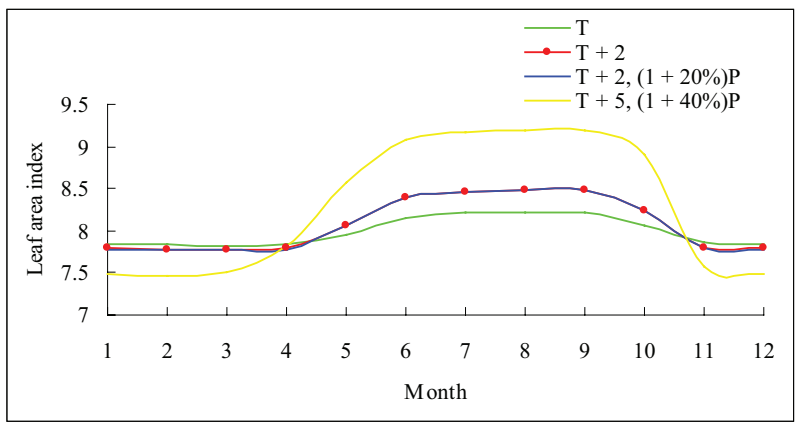

Figure 8. Mean monthly LAI averaged over the last five years 

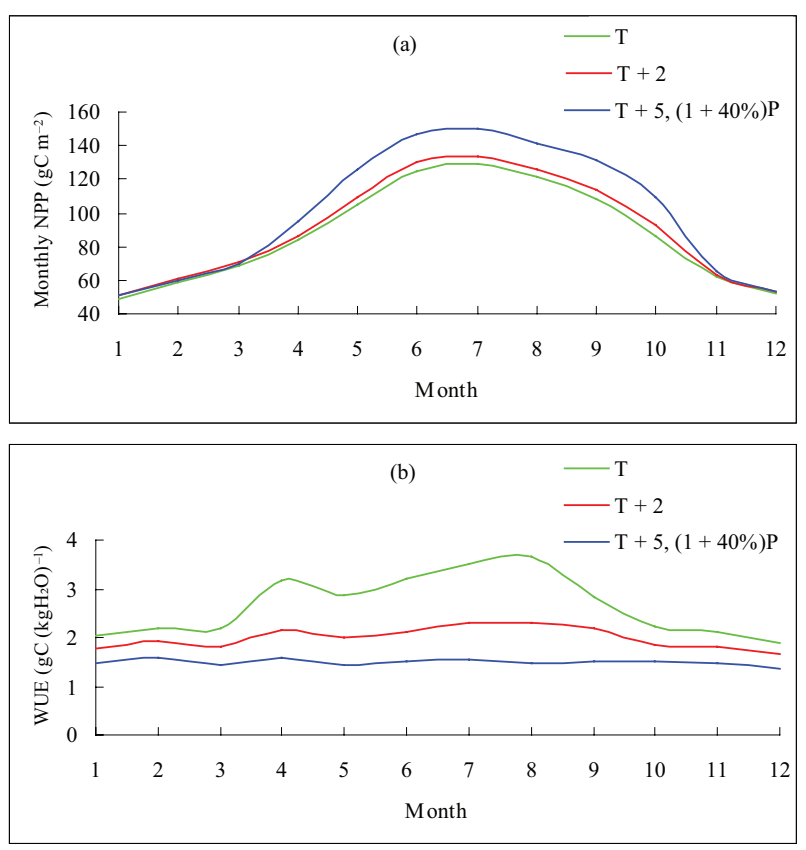

Figure 9. Mean monthly NPP and WUE averaged over the last five years: (a) NPP; and (b) WUE

Figure $9 \mathrm{~b}$ shows the monthly water use efficiency (WUE ) calculated by the ratio of the NPP to evapotranspiration. The WUE significantly decreases with an increase in temperature in the summer half-year. The annual WUE for

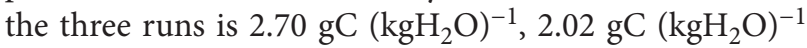
and $1.49 \mathrm{gC}\left(\mathrm{kgH}_{2} \mathrm{O}\right)^{-1}$, respectively, and decreases as the temperature increases.

\section{Discussion}

The results of the control run $\mathrm{T}$ show that forest evapotranspiration is lower than that of tundra shrub and is almost the same as that of C3 grasses. The presence of forests increases runoff compared with tundra shrubs. The results for $[\mathrm{T}+5,(1+40 \%) \mathrm{P}]$ run show that forest evapotranspiration is higher than that of tundra shrubs and C3 grasses. The presence of forest therefore reduces the annual runoff. The hydrological effects of changes in vegetation vary with temperature.

The average mean temperature of control experiment $\mathrm{T}$ is $5{ }^{\circ} \mathrm{C}$. Transpiration of forests is $129.2 \mathrm{~mm} \mathrm{yr}^{-1}$. Transpiration of tundra shrubs is $149.2 \mathrm{~mm} \mathrm{yr}^{-1}$. Transpiration of forests is lower than that of tundra shrubs owing to low temperature in the high mountainous areas. Evapotranspiration from the canopy of forests is $299.8 \mathrm{~mm} \mathrm{yr}^{-1}$. Evapotranspiration from the canopy of tundra shrubs is $268.5 \mathrm{yr}^{-1}$. Evapotranspiration from the canopy of forests is higher than that from the canopy of tundra shrubs. However, soil evaporation is significantly reduced when forests are dominant in the basin. Soil evaporation changes from $178.9 \mathrm{~mm} \mathrm{yr}^{-1}$ when tundra shrubs are dominant to $90.4 \mathrm{~mm} \mathrm{yr}^{-1}$ when forests are dominant in the basin. As the vegetation evolves from tundra shrubs to forests, evapotranspiration of the basin decreases and runoff depth increases.
The annual mean temperature of the $(\mathrm{T}+2)$ run is $7^{\circ} \mathrm{C}$. The results for $(\mathrm{T}+2)$ run show that transpiration from the canopy of forests and tundra shrubs is $208.0 \mathrm{~mm} \mathrm{yr}^{-1}$ and $198.2 \mathrm{~mm} \mathrm{yr}^{-1}$ respectively. Transpiration of forests becomes higher than that of tundra shrubs. Evapotranspiration of forests is still lower than that of tundra shrubs, but the difference between forests evapotranspiration and evapotranspiration of tundra shrubs is less than in the control experiment $\mathrm{T}$. The ability of forests to increase runoff therefore decreases as the temperature increases.

The average mean temperature of $[\mathrm{T}+5,(1+40 \%) \mathrm{P}]$ run is $10{ }^{\circ} \mathrm{C}$, and the annual precipitation is about 1000 $\mathrm{mm}$. The results produced by this run show the evapotranspiration of forests is significantly greater than that of tundra shrubs and C3 grasses as a result of a significant increase in water loss through canopy interception evaporation and transpiration from the canopy of forests. The annual evapotranspiration in this run when the surface is dominated by forests is $137 \mathrm{~mm}$ higher than that when the surface is dominated by C3 grasses and $49.7 \mathrm{~mm}$ higher than that when the surface is dominated by tundra shrubs (Table 2). Evapotranspiration reaches a maximum and the runoff depth reaches a minimum after forests become dominant in the basin. As the vegetation evolves from tundra shrubs to forests, evapotranspiration of the basin increases and runoff depth decreases.

A comparison of runoff from two small catchments (3.31 and $2.91 \mathrm{~km}^{2}$, respectively) in the upper reaches of the Minjiang River in the southwestern mountainous area showed that the alpine forests increased annual runoff (Ma, 1987). The Upper Zagunao River watershed in the upper Yangtze River is at an altitude of 1800-5800 m. The average annual temperature is $11.2^{\circ} \mathrm{C}$ and the annual precipitation ranges from $807 \mathrm{~mm}$ to $1378 \mathrm{~mm}$, with a median of $1072 \mathrm{~mm}$ (Zhang et al., 2012). Annual runoff was increased by a mean of $38 \mathrm{~mm}$ with only $15.5 \%$ of the watershed area logged and the effects of forest harvesting were completely diminished in about 20 yrs since the most intensive harvesting activities in the study watershed (Zhang et al., 2012, 2017). Results from [T+5, (1+40\%)P] run show that If forests are replaced by $\mathrm{C} 3$ grasses with $15.5 \%$ of the watershed area, the annual runoff will increase by $21.2 \mathrm{~mm}$ and will reduce to $7.7 \mathrm{~mm}$ when the surface is dominated by tundra shrubs. The five small watersheds located on the northern edge of the Sichuan Basin in the upper reaches of the Jialing River are at an altitude of $515-835 \mathrm{~m}$. The annual mean temperature is $16.1{ }^{\circ} \mathrm{C}$ and the annual mean rainfall is $937.3 \mathrm{~mm}$. Restoration of the forest reduced runoff (Zhang et al., 2007).

Evapotranspiration and runoff in the humid region of southwestern China are sensitive to changes in temperature. Evapotranspiration is not sensitive to changes in precipitation if the temperature is unchanged, but runoff is sensitive to changes in precipitation. Increase in evapotranspiration resulting from an increase in temperature reduces the soil moisture content, the groundwater table and the saturation zone, which, in turn, reduces the runoff from the basin. Among the three vegetation types, forest 
evapotranspiration shows the greatest increase with the increase of temperature. This results in a change in the forest-runoff relationship with temperature. As the temperature increases (altitude decreases), the effect of forests increasing runoff changes to a reduction in runoff. The spatial variation in the climate leads to spatial changes in the forest-runoff relationship.

Catchment comparison studies conducted at different altitudes in the southwestern mountainous region also reflect this spatial variation in the forest-runoff relationship. However, these traditional forest watershed comparison studies use a "black box" approach that focuses on the effects of a reduction in forest cover or reforestation on the streamflow measured at the outlets from the watershed and do not investigate the carbon-water cycle and vegetation dynamics within the watershed. These traditional watershed comparison studies are unable to reveal the mechanism behind the spatial variation of the forest-runoff relationship. Several different types of vegetation often coexist in the climatic zones of the basin rather than a single uniform vegetation type. The coupled SSiB4T/TRIFFID model is able to deal with the spatial heterogeneity of vegetation and to simulate the vegetation dynamics and carbon-water cycle to investigate biosphere-hydrosphere interactions at the basin scale. This can overcome the shortcomings of traditional forest catchment research and can be used to investigate the response of vegetation dynamics and surface water budget to the changing climate.

\section{Conclusions}

We coupled the SSiB4/TRIFFID dynamic vegetation model with TOPMODEL to investigate the effects of climate change on vegetation and the surface water balance at a basin scale in a mountainous region of southwestern China. We performed long-term simulations of vegetation dynamics and the water balance under different climate scenarios for the subalpine Suomo river basin. Based on the simulation results, we analyzed the effects of changes in climate and vegetation on the surface water balance and investigated the factors and mechanisms that control the variation in the forest-runoff relationship.

Our main conclusions are as follows. (1) The forest type basically changes from coniferous forest to coniferous and broadleaf mixed forest as the temperature increases. (2) Among the three vegetation types of $\mathrm{C} 3$ grasses, tundra shrubs and forests, the LAI of forests is the most sensitive to changes in temperature and clearly increases with temperature during the growing season. (3) Evapotranspiration in the humid subalpine mountain region is very sensitive to changes in temperature, but is not sensitive to changes in precipitation when the temperature remains unchanged. Runoff is very sensitive to changes in both temperature and precipitation. (4) Among the three vegetation types, evapotranspiration from forests increases the most with increasing temperature as a result of a significant increase in water loss through canopy interception evaporation and transpiration. (5) The WUE of the forest ecosystem decreases as the temperature increases. (6) The role of forests in increasing runoff changes to a reduction in runoff as the temperature increases or the altitude decreases. The vertical climatic zone has an important impact on this relationship in the mountainous region of southwestern China.

\section{Acknowledgements}

This study was jointly supported by the project of $\mathrm{Na}$ tional Natural Science Foundation of China (Grant No. 41630532) and the National Key Research and Development Program of China (2018YFA0606004). We also appreciate two anonymous reviewers' detailed comments and very constructive suggestions.

\section{Author contributions}

Huiping Deng and Li Dan incorporated TOPMODEL into the SSiB4/TRIFFID and designed the simulation experiments. Huiping Deng and Huanguang Deng performed the simulation experiments. Huiping Deng, Yan Xiao and Qian Wang draft all the figures. Huiping Deng and Li Dan analyzed the output and prepared the manuscript with contributions from all authors.

\section{Conflict of interest}

We all declare that we have no conflict of interest in this paper.

\section{References}

Arnell, N. W. (2003). Relative effects of multi-decadal climatic variability: Future streamflows in Britain. Journal of Hydrology, 270(3-4), 195-213.

https://doi.org/10.1016/S0022-1694(02)00288-3

Beven, K. J., \& Kirkby, M. J. (1979). A physical based variable contributing area model of basin hydrology. Hydrological Science Bulletin, 24(1), 43-69. https://doi.org/10.1080/02626667909491834

Beven, K. J. (2000). Rainfall-Runoff modeling. In Encyclopedia of hydrological sciences (Part 11). John Wiley \& Sons.

Bonan, G. B., Levis, S., Sitch, S., Vertenstein, M., \& Oleson, K. W. (2003). A dynamical global vegetation model for use with climate models: Concepts and description of simulated vegetation dynamics. Global Change Biology, 9(11), 1543-1566. https://doi.org/10.1046/j.1365-2486.2003.00681.x

Bosch, J. M., \& Hewlett, J. D. (1982). A review of catchment experiments to determine the effect of vegetation changes on water yield and evapotranspiration. Journal of Hydrology, 55(1-4), 3-23. https://doi.org/10.1016/0022-1694(82)90117-2

Chen, J., \& Kumar, P. (2001). Topographic influence on the seasonal and interannual variation of water and energy balance of basins in North America. Journal of Climate, 14(9), 19892012. https://doi.org/10.1175/1520-0442(2001)014<1989:TIO TSA $>2.0 . C O ; 2$

Cheng, G. W. (1991). An approach to the relationship between runoff characters and forest in the basin of Sichuan. Journal of Soil and Water Conservation, 5(1), 48-52 (in Chinese). 
Cowling, S. A., Jones, C. D., \& Cox, P. M. (2009). Greening the terrestrial biosphere: Simulated feedbacks on atmospheric heat and energy circulation. Climate Dynamics, 32, 287-299. https://doi.org/10.1007/s00382-008-0481-8

Cox, P. M., Betts, R. A., Jones, C. D., Spall, S. A., \& Totterdell, L. J. (2000). Acceleration of global warming due to carbon-cycle feedbacks in a coupled climate model. Nature, 408, 184-187. https://doi.org/10.1038/35041539

Cox, P. M., Betts, R. A., Jones, C. D., Spall, S. A., \& Totterdell, I. J. (2001). Modelling vegetation and the carbon cycle as interactive elements of the climate system. In R. Pearce (Ed.), Meteorology at the Millennium (pp. 259-279). Academic Press. https://doi.org/10.1016/S0074-6142(02)80172-3

Dan, L., Ji, J., \& He, Y. (2007). Use of ISLSCP II data to intercompare and validate the terrestrial net primary production in a land surface model coupled to a general circulation model. Journal of Geophysical Research: Atmospheres, 112(D2), D02S90. https://doi.org/10.1029/2006JD007721

Dan, L., Ji, J., Xie, Z. H., Chen, F., Wen, G., \& Richey, J. E. (2012). Hydrological projections of climate change scenarios over the $3 \mathrm{H}$ region of China: A VIC model assessment. Journal of Geophysical Research: Atmospheres, 117(D11), 1-17. https://doi.org/10.1029/2011JD017131

Deng, H. P., \& Sun, S. F. (2012). Incorporation of TOPMODEL into land surface model SSiB and numerically testing the effects of the corporation at basin scale. Science China Earth Sciences, 55, 1731-1741.

https://doi.org/10.1007/s11430-012-4431-2

Diaz-Nieto, J., \& Wilby, R. L. (2005). A comparison of statistical downscaling and climate change factor methods: Impacts on low flows in the River Thames, United Kingdom. Climate Change, 69, 245-268.

https://doi.org/10.1007/s10584-005-1157-6

Douville, H. (2003). Assessing the influence of soil moisture on seasonal climate variability with AGCMs. Journal of Hydrometeorology, 4(6), 1044-1066. https://doi.org/10.1175/15257541(2003)004<1044:ATIOSM>2.0.CO;2

Dunn, S. M., \& Mackay, R. (1995). Spatial variation in evapotranspiration and the influence of land use on catchment hydrology. Journal of Hydrology, 171(1-2), 49-73. https://doi.org/10.1016/0022-1694(95)02733-6

Gedney, N., \& Cox, P. M. (2003). The sensitivity of globle climate model simulations to the representation of soil moisture heterogeneity. Journal of Hydrometeorology, 4(6), 1265-1275. https://doi.org/10.1175/1525-7541(2003)004<1265:TSOGCM $>2.0$.CO;2

Gerten, D., Sibyll, S., Uwe, H., Wolfgang, L., \& Stephen, S. (2004). Terrestrial vegetation and water balance - hydrological evaluation of a dynamic global vegetation model. Journal of Hydrology, 286(1-4), 249-270. https://doi.org/10.1016/j.jhydrol.2003.09.029

Koster, R. D., Suarez, M. J., Ducharne, A., Stieglitz, M., \& Kumar, P. (2000). A catchment-based approach to modeling land surface processes in a general circulation model, 1. Model structure. Journal of Geophysical Research, 105(D20), 809822. https://doi.org/10.1029/2000JD900327

Li, W. H., He, Y. T., \& Yang, L. Y. (2001). A summary and perspective of forest vegetation impacts on water yield. Journal of Natural Resources, 16(5), 398-406 (in Chinese). http://www.jnr.ac.cn/EN/abstract/abstract26372.shtml

Liu, Y., Xue, Y., MacDonald, G., Cox, P. M., \& Zhang, Z. (2019). Global vegetation variability and its response to elevated $\mathrm{CO}_{2}$, global warming, and climate variability - a study using the offline SSiB4/TRIFFID model and satellite data. Earth System Dynamics, 10(1), 9-29. https://doi.org/10.5194/esd-10-9-2019
Ma, X. H. (1987). Preliminary study on hydrological function of fir forest in Miyaluo region of Sichuan. Scientia Silves Sinicae, 23, 253-264 (in Chinese).

Minville, M. F., Brissette, F., \& Leconte, R. (2008). Uncertainty of the impact of climate change on the hydrology of a Nordic watershed. Journal of Hydrology, 358(1-2), 70-83. https://doi.org/10.1016/j.jhydrol.2008.05.033

Niu, G.-Y., Yang, Z.-L., Dickinson, R. E., \& Gulden, L. E. (2005). A simple TOPMODEL-based runoff parameterization (SIMTOP) for use in global climate models. Journal of Geophysical Research, 110(D21), 1-15.

https://doi.org/10.1029/2005JD006111

Peng, J., \& Dan, L. (2015). Impacts of $\mathrm{CO}_{2}$ concentration and climate change on the terrestrial carbon flux using six global climate-carbon coupled models. Ecological Modelling, 304, 69-83. https://doi.org/10.1016/j.ecolmodel.2015.02.016

Sellers, P. J., Mintz, Y., Sud, Y. C., \& Dalcher, A. (1986). A Simple Biosphere Model ( $\mathrm{SiB}$ ) for use within general circulation models. Journal of the Atmospheric Science, 43(6), 505-531. https://doi.org/10.1175/1520-0469(1986)043<0505:ASBMFU $>2.0$.CO;2

Sellers, P. J., Randall, D. A., Collatz, G. J., Berry, J. A., Field, C. B., Dazlich, D. A., Zhang, C., Collelo, G. D., \& Bounoua, L. (1996). A revised land surface parameterization (SiB2) for atmospheric GCMs. Journal of Climate, 9(4), 676-705.

https://doi.org/10.1175/1520-0442(1996)009<0676:ARLSPF> 2.0.CO;2

Sellers, P. J., Dickinson, R. E., Randall, D. A., Betts, A. K., Hall, F. G., Berry, J. A., Collatz, G. J., Denning, A. S., Mooney, H. A., Nobre, C. A., Sato, N., Field, C. B., \& HendersonSellers, A. (1997). Modeling the exchanges of energy, water, and carbon between continents and the atmosphere. Science, 275(5299), 502-509.

https://doi.org/10.1126/science.275.5299.502

Sheffield, J., Goteti, G., \& Wood, E. F. (2006). Development of a 50 -yr high-resolution global dataset of meteorological forcings for land surface modeling. Journal of Climate, 19(13), 3088-3111. https://doi.org/10.1175/JCLI3790.1

Sivapalan, M., Beven, K. J., \& Wood, E. F. (1987). On hydrologic similarity: 2. A scaled model of storm runoff production. Water Resource Research, 23(12), 2266-2278.

https://doi.org/10.1029/WR023i012p02266

Stieglitz, M., Rind, D., Famiglieth, J., \& Rosenzweig, C. (1996). An efficient approach to modeling the topographic control of surface hydrology for regional and global climate modeling. Journal of Climate, 10(1), 118-137. https://doi. org/10.1175/1520-0442(1997)010<0118:AEATMT>2.0.CO;2

United States Geological Survey. (2003). Shuttle Radar Topography Mission documentation: SRTM Topo [EB/OL]. https://pubs.er.usgs.gov/publication/fs07103

Warrach, K., Stieglitz, M., Mengelkamp, H. T., \& Raschke, E. (2002). Advantages of a topographically controlled runoff simulation in a soil-vegetation-atmosphere transfer model. Journal of Hydrometeorology, 3(2), 131-148. https://doi. org/10.1175/1525-7541(2002)003<0131:AOATCR>2.0.CO;2

Woodward, F. I., Lomas, M. R., \& Kelly, C. K. (2004). Global climate and the distribution of plant biomes. Philosophical Transactions of the Royal Society B, 359(1450), 1465-1476. https://doi.org/10.1098/rstb.2004.1525

Xue, Y. K., Sellers, P. J., Kinter, J. L., \& Shukla, J. (1991). A simplified biosphere model for global climate studies. Journal of Climate, 4(3), 345-364. https://doi.org/10.1175/15200442(1991)004<0345:ASBMFG>2.0.CO;2 
Xue, Y. K., Deng, H. P., \& Cox, P. M. (2006). Testing a coupled biophysical/dynamic vegetation model (SSiB-4/TRIFFID) in different climate zones using satellite-derived and groundmeasured data. In $86^{\text {th }}$ AMS Annual Meeting, $18^{\text {th }}$ Conference on Climate Variability and Change. https://ams.confex.com/ ams/Annual2006/webprogram/Paper101721.html

Zeng, Z. Z., Piao, S. L., Li, L. Z. X., Wang T., Ciais, P., Lian, X., Yang, Y., Mao, J., Shi, X., \& Myneni, R. (2018). Impact of earch greening on the terrestrial water cycle. Journal of Climate, 31(7), 2633-2650. https://doi.org/10.1175/JCLI-D-17-0236.1

Zhan, X. W., Xue, Y. K., \& Collatz, G. J. (2003). An analytical approach for estimating $\mathrm{CO}_{2}$ and heat fluxes over the Amazonian region. Ecological Modeling, 162(1-2), 97-117. https://doi.org/10.1016/S0304-3800(02)00405-2

Zhang, F. H., Chen, L. W., Wu, X. X., \& Gong, Y. B. (2007). An analysis of influences of forest vegetation changes on the runoff in small watersheds in hilly areas in the upper reaches of the Yangtze River. Journal of Sichuan Forestry Science and Technology, 28(4), 49-53 (in Chinese).
Zhang, M. F., Wei, X. H., Sun, P. S., \& Liu, S. R. (2012). The effect of forest harvesting and climatic variability on runoff in a large watershed: The case study in the Upper Minjiang River of Yangtze River basin. Journal of Hydrology, 464-465, 1-11. https://doi.org/10.1016/j.jhydrol.2012.05.050

Zhang, M. F., Liu, N., Harper, R., Li, Q., Liu, K., Wei, X. H., Ning, D. Y., Hou, Y. P., \& Liu, S. R. (2017). A global review on hydrological responses to forest change across multiple spatial scales: Importance of scale, climate, forest type and hydrological regime. Journal of Hydrology, 546, 44-59. https://doi.org/10.1016/j.jhydrol.2016.12.040

Zhang, Z. Q., Xue, Y. K., MacDonald, G., Cox, P. M., \& Collatz, G. J. (2015). Investigation of North American vegetation variability under recent climate: A study using the SSiB4/ TRIFFID biophysical/dynamic vegetation model. Journal of Geophysical Research: Atmospheres, 120(4), 1300-1321. https://doi.org/10.1002/2014JD021963 